\title{
Tecnologie immersive per la valorizzazione del patrimonio storico. I modelli digitali della Scuola del Carmine
}

\author{
Rachele Angela Bernardello \\ Isabella Friso \\ Giulia Piccinin
}

\section{Abstract}

La ricerca [I] propone l'analisi del ciclo pittorico cinquecentesco conservato nella scuola del Carmine di Padova, sede di una delle più antiche fraglie della città. In questa occasione si offrono gli esiti della ricerca, le cui premesse sono state presentate in passato, durante la fase iniziale del lavoro [2]. Le diciassette quadrature che compongono l'opera narrano gli episodi salienti della vita della Vergine Maria tratti dai Vangeli apocrifi. Obiettivo del progetto è la valorizzazione del patrimonio artistico e architettonico dei siti culturali minori, esclusi dai tradizionali percorsi turistici della città.

Le attività di ricerca sono state organizzate in maniera da: a) acquisire il dato formale (tecnologie Laser Scanner 3D, fotogrammetriche, termografiche, georadar) e le informazioni storiche (ricerche d'archivio); b) costruire un database interoperabile che raccolga documentazioni, informazioni, interpretazioni relative al caso studio; c) creare attraverso tecnologie Scan-to-BIM un modello virtuale interoperabile dell'architettura rilevata; d) implementare modelli 3D con dati infografici provenienti dal database, ottenendo un modello semantico (geometria, informazioni, documenti, immagini storiche, valori termo-igrometrici di progetto e rilevati ecc.); e)testare su strumenti innovativi la navigazione e interrogazione del modello semantico.

Parole chiave

Cultural Heritage, restituzione prospettica, tecnologie immersive, BIM, museo virtuale.

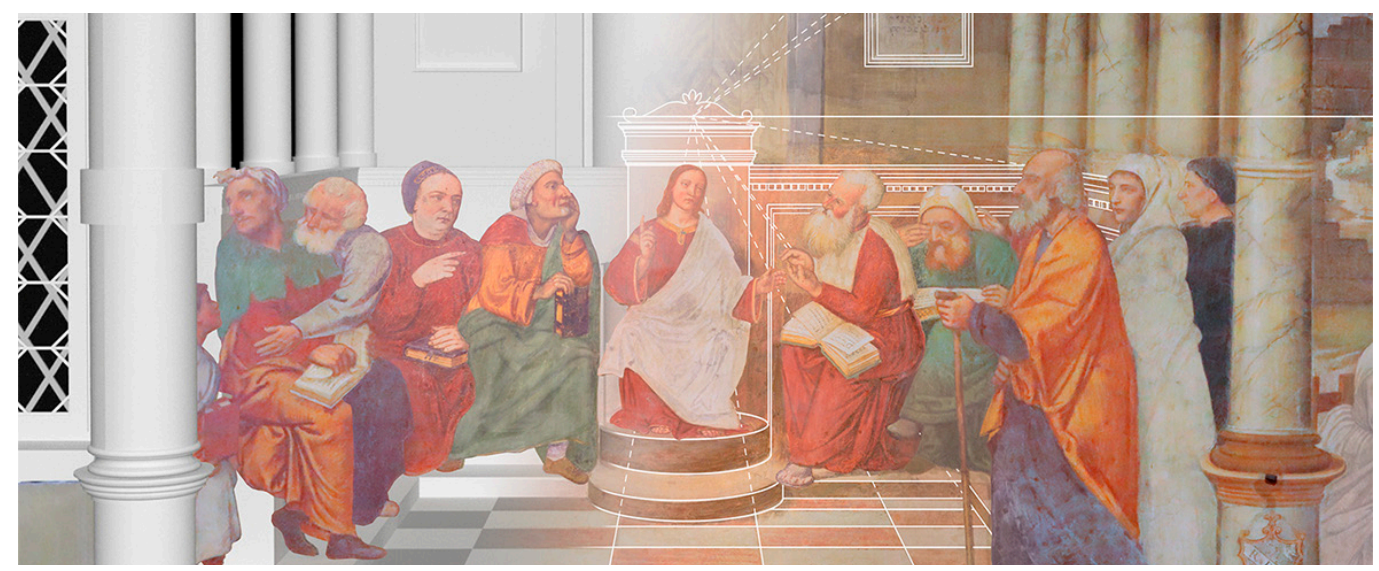




\section{Dal rilievo al digitale: un percorso di ricostruzione di architetture dipinte}

La ricostruzione digitale delle architetture raffigurate all'interno di cicli pittorici è un tema molto frequente che consente di mettere in relazione tra loro i molteplici aspetti legati alla scienza della rappresentazione: infatti, pur risultando fondamentali le applicazioni di tecniche recenti, quale il rilievo digitale, e la produzione di immagini ottenute con l'ausilio di strumenti informatizzati, non ci si può esimere dal ricorrere ai dettami teorici che la geometria descrittiva impone, facendo infatti ricorso alla conoscenza delle leggi proiettive proprie delle proiezioni centrali e, nello specifico, della prospettiva.

II ciclo pittorico cinquecentesco presente sulle pareti della più antica fraglia dei Carmini (figg. I, 2) è il caso studio prescelto poiché registra tutte le caratteristiche richieste per effettuare questo tipo di processo: seppur allocato allinterno di uno dei più antichi e importanti complessi monastici nel centro storico di Padova, le maestranze locali non hanno adempito ad una sua adeguata valorizzazione dal momento che rimane per lo più estraneo ai circuiti turistici e, al più, sconosciuto anche dai cittadini.

Partendo allora da un'indagine storica e d'archivio, il primo passo della ricerca ripercorre cronologicamente le tappe di un processo evolutivo che sottolinea quelle che sono state le principali trasformazioni - a carattere urbano e architettonico - dell'intero complesso dei Carmini, inclusa la chiesa, il convento e, ovviamente, la Scuola che ospita il ciclo.

Lo step successivo prevede una campagna di rilievo digitale con tecnologie laser-scanner e fotogrammetriche per documentare fedelmente lo stato di fatto e realizzare poi un clone semantico dell'architettura: i documenti d'archivio affiancati alle nuvole di punti, costituiscono dunque il substrato culturale sul quale il clone informatizzato - realizzato in ambiente BIM - dell'involucro edilizio pone le proprie fondamenta. II modello texturizzato ottenuto dall'elaborazione della dense-cloud [Ciammaichella, Bergamo 20I6] garantisce inoltre la produzione delle quattro ortofoto delle pareti, necessarie per l'analisi e la restituzione dei modelli digitali delle architetture dipinte da Giulio e Domenico Campagnola, Girolamo dal Santo e Stefano dell'Arzere.

Infine, un'indagine georadar ha consentito di rilevare ed evidenziare eventuali anomalie costruttive e modifiche strutturali dell'edificio.

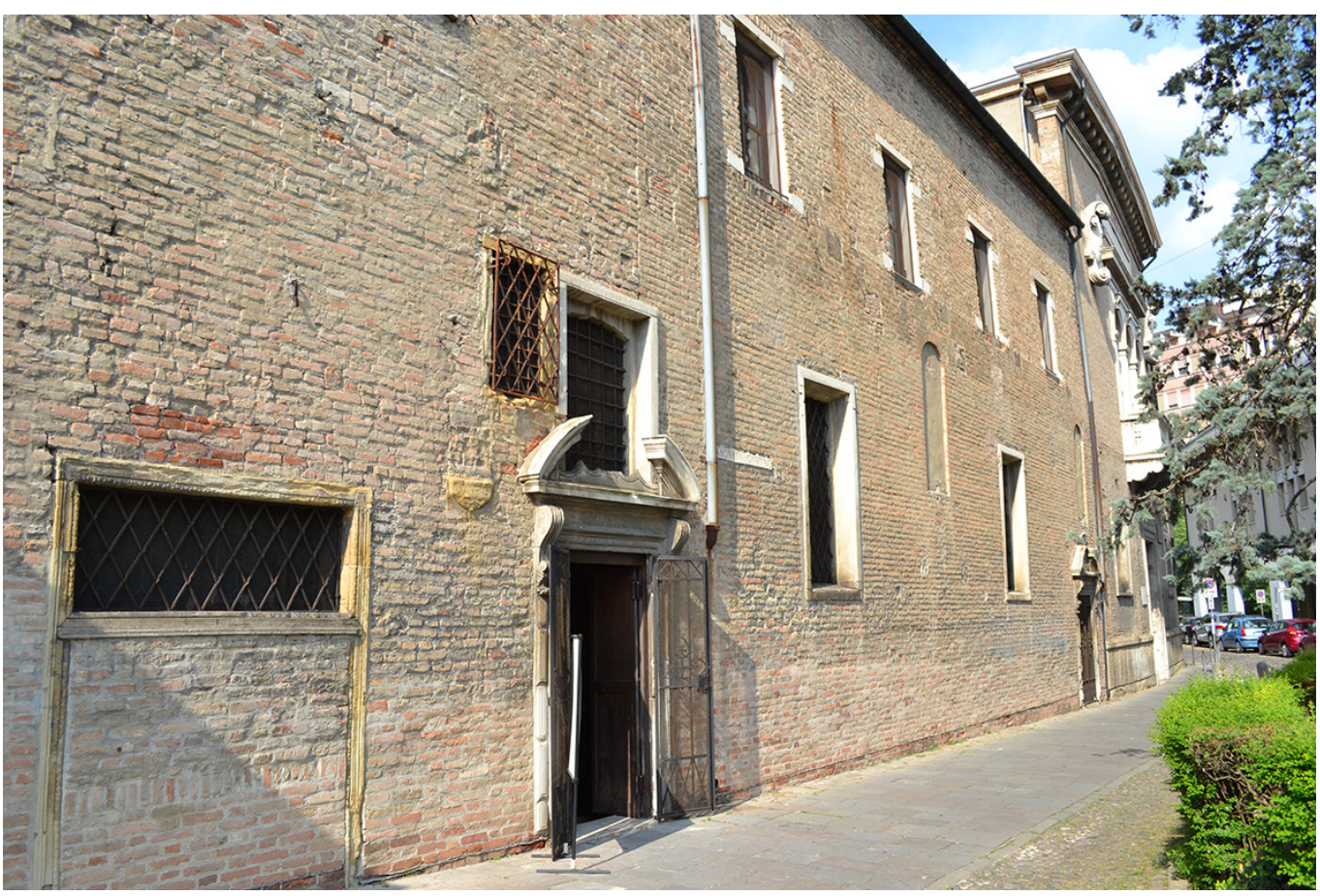


II ciclo pittorico sulle pareti della scoletta, è stato affrescato in un sistema di colonne su basamento a sostegno di una trabeazione: tale apparato, anch'esso rappresentato in prospettiva - a quadro verticale -, rimanda ad un sistema virtualmente strutturale, con lo scopo di ripartire il piano pittorico in riquadri pressoché uguali, in ciascuno dei quali si delinea il racconto della vita della Vergine Maria. Si è partiti dalla individuazione dell'orientazione prospettica interna [Sgrosso 1979] di ogni episodio narrato e, di conseguenza, l'esatta posizione dell'occhio dell'osservatore nello spazio reale [3]. Tuttavia bisogna fare alcune osservazioni di carattere prospettico: in primis, l'orientazione esterna, e cioè la scelta della retta fondamentale, è stata ritenuta coincidente con il bordo inferiore delle quadrature (a circa $182 \mathrm{~cm}$ dal pavimento), al limite del basamento dipinto; per questo l'altezza dell'osservatore di ciascun dipinto non coincide con quella effettiva (fig. 3): infatti, la posizione ideale dell'osservatore non tiene conto della realtà spaziale del costruito, non corrispondendo ad un particolare punto strategico all'interno della sala; inoltre, proprio per questa 'varietà' di orientazioni, sembra che l'osservatore sia liberamente in movimento e a distanza non costante dagli affreschi. Pertanto, l'intento progettuale, fedele al contenuto della narrazione, non si sviluppa nelle procedure di realizzazione in maniera coerente. Tale fenomeno è indubbiamente giustificabile dalla presenza in cantiere di maestranze di diversa formazione per un lasso temporale molto lungo. Dunque la reale posizione dei centri di proiezione si configura come percorso fruitivo in cui l'osservatore, seppur vincolato alla lettura della narrazione, deve muoversi.

Tutte le scene del ciclo pittorico sono state rappresentate applicando le regole geometriche della prospettiva a quadro verticale: in particolare, laddove sono rappresentati degli edifici, questi mantengono invariata la verticalità delle loro altezze e sono disposti con alcune delle facciate parallele al quadro (in quanto figure appartenenti a piani paralleli ad esso).

La corrispondenza omologica che lega l'immagine prospettica e la sua prima proiezione mongiana (ribaltata al di sotto della fondamentale) ha consentito di determinare, applicando inversamente il metodo del ribaltamento, la configurazione planimetrica degli edifici raffigurati. Con la stessa procedura sono state, in un secondo momento, restituite le altezze che hanno permesso di delineare le facciate degli stessi edifici (Sgrosso I 979, pp. 8- 19). I grafici desunti dalle restituzioni prospettiche sono stati elaborati nelle tre dimensioni dello spazio virtuale (fig. 4).

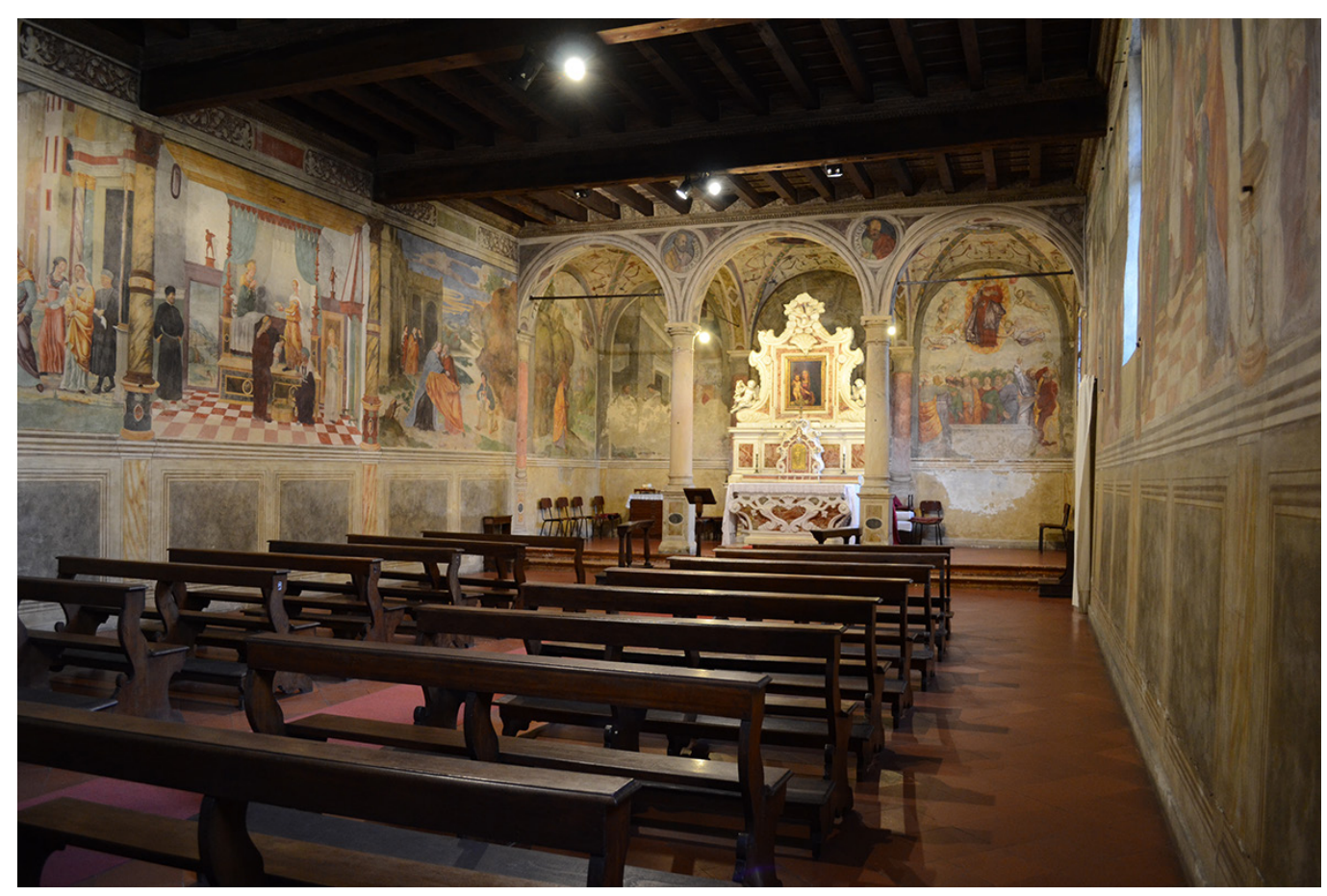


Quanto restituito è stato di fondamentale importanza per la fase successiva della ricerca che riguarda la sperimentazione in campi inerenti l'Augmented Reality e l'Immersive Reality, recenti tecnologie che aprono nuove frontiere nel campo della Rappresentazione, abbattendo i limiti fisici imposti dal supporto cartaceo e trasformando l'osservatore da fruitore passivo a protagonista interattivo.

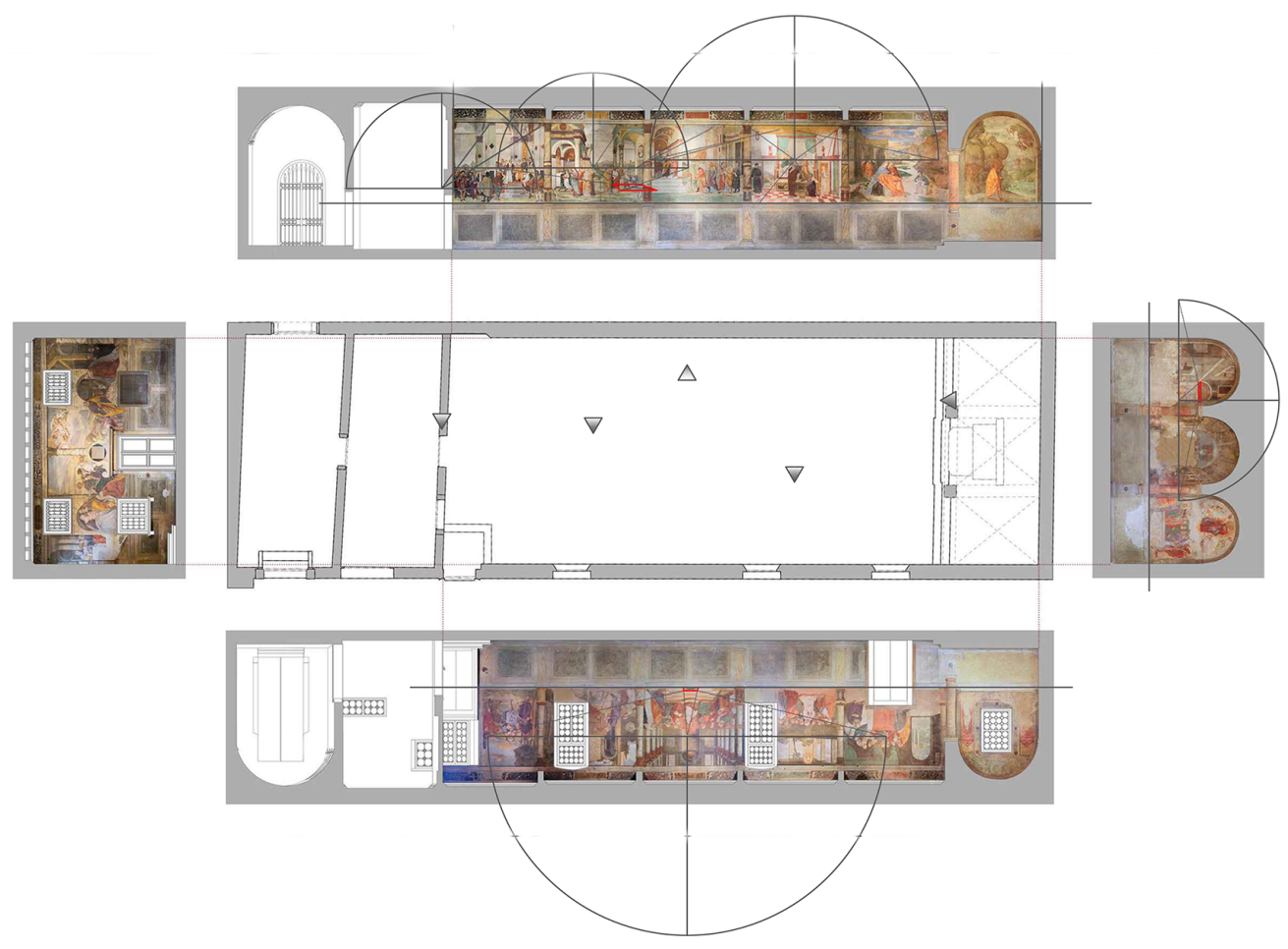

\section{Scoletta del Carmine tra architettura costruita e architettura dipinta}

La concezione di spazio all'interno della scoletta è formulata in una congiunta relazione tra l'ambiente costruito e lo spazio dipinto [4], solamente osservabile senza potervi entrare. Entrambi esistono con delle proprie regole e una propria codifica, ma ognuno necessariamente subisce ed esercita un'influenza sull'altro, modificando la percezione del fruitore sulla dimensione in cui è immerso e che osserva.

II processo di ricostruzione Scan-to-BIM dell'antica sede della fraglia ha permesso tramite la nuvola di punti di poter gestire, discretizzare e rappresentare in ambiente virtuale le informazioni sia architettoniche che pittoriche. A partire dal rilievo quindi sono proseguiti percorsi paralleli per poter restituire le due dimensioni e per poter usufruire, almeno nello spazio virtuale, della loro interazione spaziale, creata nella realtà dal processo visivo dell'osservatore.

In particolare, tramite una ricostruzione visiva delle trasformazioni dello spazio materico avvenute nel tempo, i cambiamenti architettonici di demolizione e ricostruzione sono stati portati alla luce ed esplorati tramite applicazioni virtuali [Giordano et al 20 18, p. 52].

La connessione e l'interdipendenza tra geometria, parametri e relazioni stesse, proprie della modellazione ad oggetti, impiegata per la ricostruzione degli apparati architettonici, ha permesso di interrogare ed esplicitare nel clone digitale la struttura as built, assieme ai diversi eventi che hanno modificato l'antico Refettorio, mediante la mappatura e l'organizzazione dei documenti d'archivio e delle fonti storiche. 
In linea con questa logica, l'architettura dipinta è stata trattata all'interno del modello BIM come un sistema costruito. Ciascun quadro pittorico è stato infatti considerato come un componente effettivo ed unico all'interno del modello, descrivendone non solo i vari parametri dimensionali, ma anche arricchendolo di relative informazioni tra cui autore, riferimenti bibliografici e metodo di trasferimento del disegno [5]. L'organismo architettonico filtro, ovvero colonne e trabeazione, che inquadra i singoli affreschi e che consente di rendere credibile l'effetto esterno-interno, è stato identificato come elemento esclusivo, integrato con una sua identità e funzione sia nel database costituito dal modello che conseguentemente nelle elaborazioni negli strumenti di visualizzazione.

La dimensione temporale viene così inserita nel modello BIM attraverso l'organizzazione di tipi diversi di parametri e la compilazione di un valore per ciascun oggetto. II passaggio poi dalla datazione dei singoli elementi alla creazione di macro-fasi, consente di filtrare e raggruppare le informazioni secondo criteri dettati dall'uso del modello, in particolare per la scoletta le modifiche architettoniche che hanno avuto un effetto negli affreschi:

- 1313-1492: periodo di costruzione del convento di Santa Maria del Carmelo: l'ambiente dell'attuale scoletta è adibito a refettorio dei frati.

- |492-I505: dopo il crollo della parete est della chiesa, la sede della fraglia è spostata al piano terra della, hanno così inizio i lavori di decorazione pittorica della scoletta.
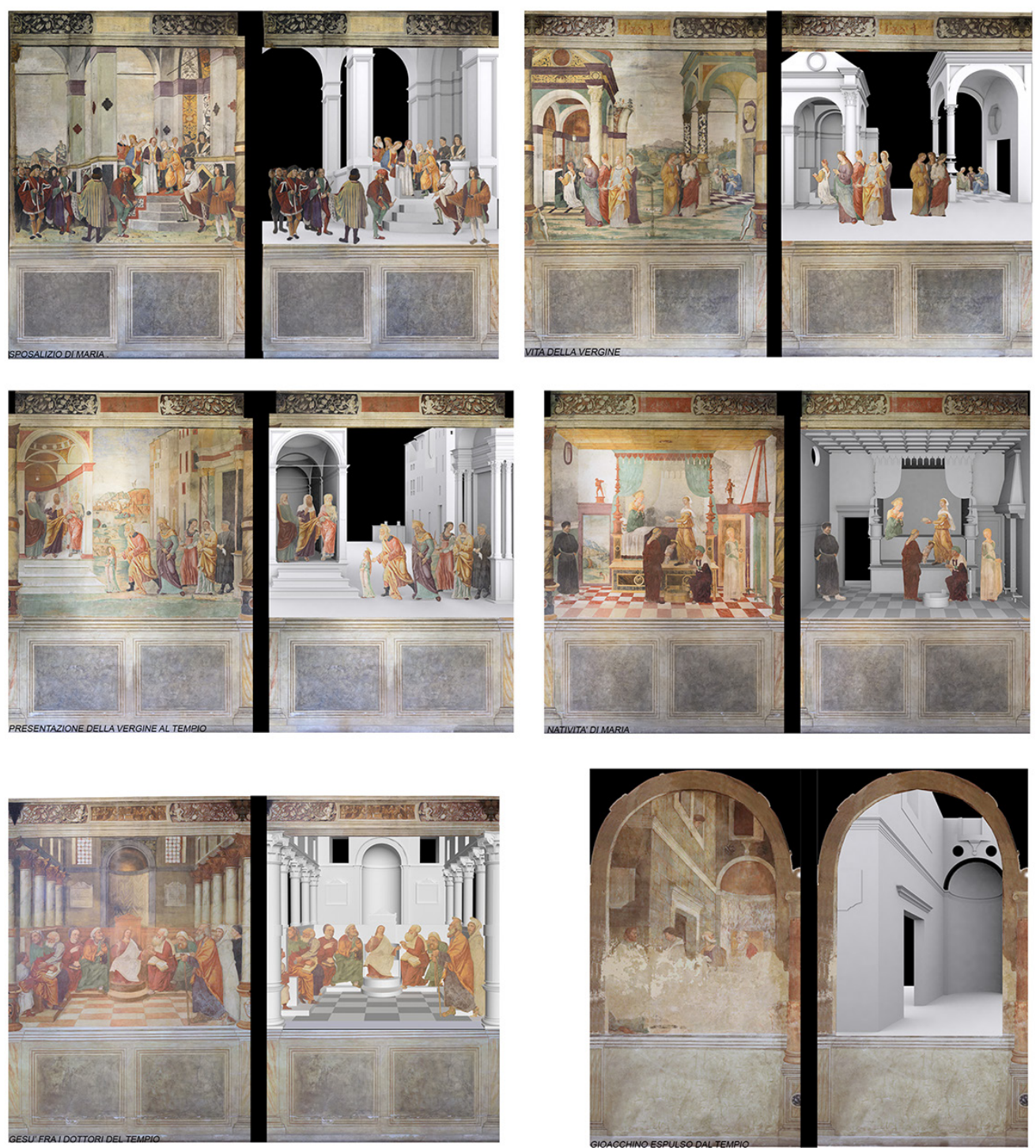
- I505- 1600: chiusura dell'attuale ciclo pittorico, con la costruzione di un muro - attuale muro ovest - che divide la scoletta dalla sacrestia.

- 1600-20 I 8: soppressione della fraglia e, in particolare, vengono inserite le due attuali porte di accesso dal sagrato e modificata una finestra in porta. Spostamento dell'altare dalla parete est.

In questo modo, esplorando e interrogando il modello è possibile spostarsi lungo la linea del tempo, comprendendo non solo le modifiche architettoniche interne, ma visualizzando il ciclo pittorico nei diversi momenti storici. Ad esempio, visitare la scoletta senza la presenza del muro ovest eretto dalla confraternita, in assenza quindi delle scene su di esso [6], cogliendo così nella sua interezza la prima conformazione con gli affreschi dell'attuale atrio, ora solo parzialmente visibili. Inoltre la possibilità di integrare nel modello digitale informativo la ricostruzione tridimensionale degli ambienti dipinti, ottenuti dalla restituzione prospettica, fornisce per ciascuna fase un ulteriore livello di immersione potendo entrare in uno scenario generalmente immobile che fa da sfondo al movimento dei corpi.

È da sottolineare come lo stato di conservazione degli affreschi sia connesso all'uso dello spazio costruito e alla sua natura strutturale. Nel corso del tempo cambi di funzione hanno causato perdite e deterioramento di superficie affrescata, come ad esempio per gli spostamenti dell'altare. II modello BIM quindi è la base per effettuare analisi e simulazioni, per supportare le attività di conoscenza e conservazione degli affreschi cinquecenteschi (Volk 20 I4, p. I I0). Una sovrapposizione della nuvola di punti con il modello BIM ha permesso di evidenziare difformità strutturali e fuori piombo delle murature, in particolare ai fini della ricostruzione prospettica degli ambienti degli affreschi è stato possibile determinare l'inclinazione del piano del quadro.
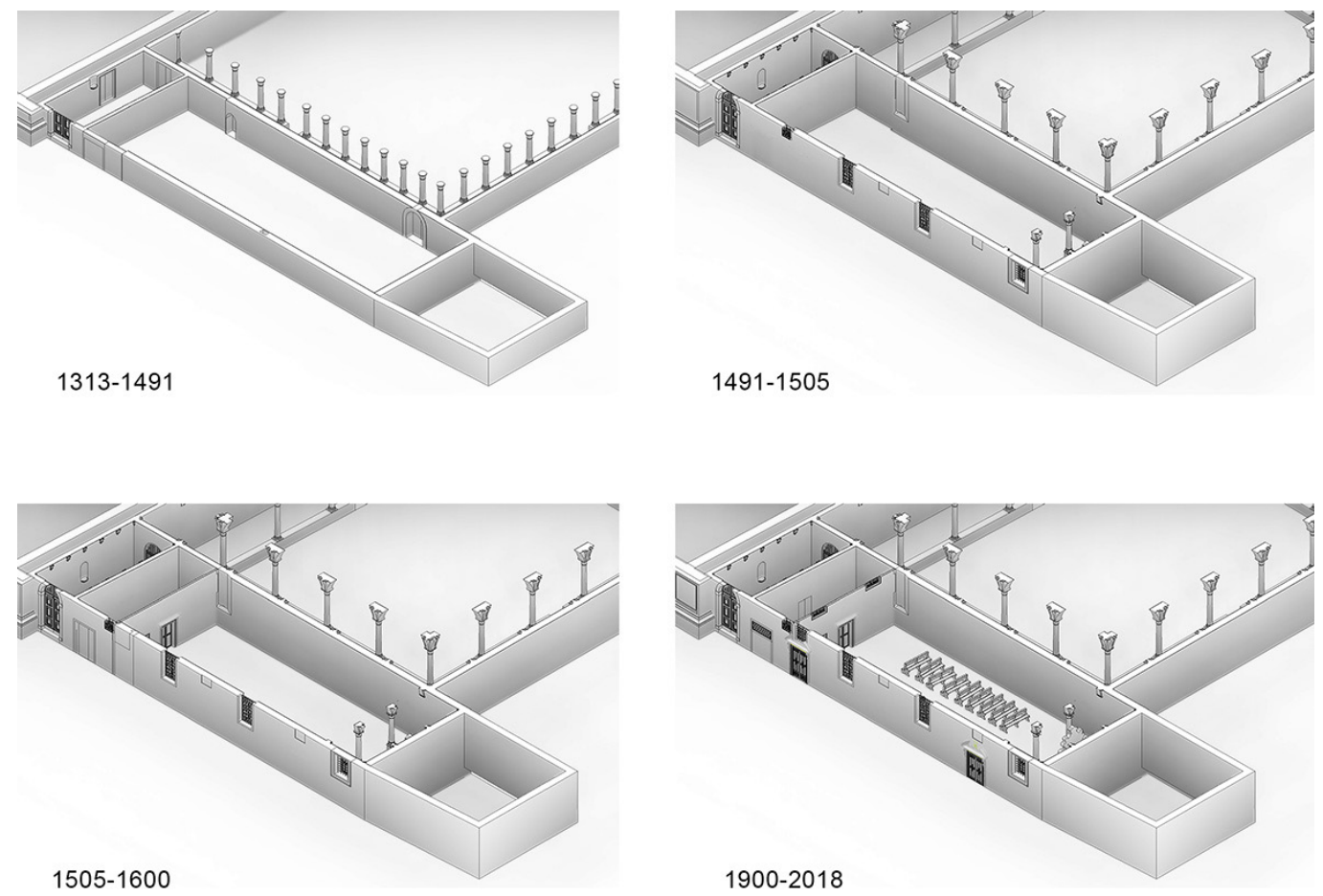

\section{Gli ambienti della scuola attraverso realtà aumentata e realtà virtuale}

La modellazione tridimensionale, strumento indispensabile per integrare gli ambienti che sono tra loro diversi per natura, permette di uniformarli facendo confluire informazioni complementari in un unico ambiente, quello immateriale della virtualità. L'applicazione rigorosa delle procedure di analisi e modellazione ha permesso la produzione di un bagaglio 
di informazioni provenienti dai diversi ambiti di ricerca coinvolti. Le tecnologie immersive sperimentate in questa occasione forniscono la possibilità di organizzare tali informazioni e renderle fruibili per un duplice intento: di controllo, ai fini della manutenzione e gestione, ma soprattutto di fruibilità da parte del pubblico, in termini di visita museale. Scelti tra quelli disponibili nel mercato, i device selezionati per la sperimentazione dei modelli digitali hanno dimostrato, confrontando i risultati forniti, capacità di resa, costi e modalità di utilizzo tra loro differenti. Nel tentativo di coinvolgerei un pubblico vasto, la scelta della strumentazione ha inoltre tenuto conto delle caratteristiche dellipotetico utilizzatore finale: età, livello di formazione, background culturale e interessi. Per questo i dispositivi adottati variano in maniera sostanziale per il grado di libertà lasciato all'utente di personalizzare la propria fruizione.

Un HeadMountedDisplay-HMD [7] (fig. 6) ha concesso principalmente la possibilità di predisporre un tour predefinito, supportando le diverse tipologie di dati di input: i modelli digitali e la point-cloud fornita dalla campagna di rilievo, le immagini, i file audio. In questa ipotesi lo strumento esclude l'ideale visitatore dalla realtà tangibile al quale è familiare: il suo movimento fisico, infatti, non è coinvolto nella visita virtuale. Maggiore libertà, seppur comunque confinata, è concessa all'ipotetico visitatore nell'ipotesi di fruizione dei modelli all'interno di una camera immersiva [8]; in questo caso l'utente, che si trova al suo interno ed è dotato di controller e appositi occhiali LCD, può navigare nell'ambiente virtuale e interrogare il modello (fig. 7) per ottenere le informazioni di tipo metrico/geometrico - derivanti dalla pointcloud (fig. 8) - e documentale, testi, immagini, audio. Una volta selezionata la fase storica di interesse, è possibile per esempio visualizzare per intero il ciclo pittorico originale, completo delle quadrature presenti oggi nella sacrestia, o interrogare appositi tag che ripercorrono le vicende legate alla presenza dell'ordine dei carmelitani a Padova, o ancora visualizzare le fonti quali documenti antichi o mappe storiche.

Allinterno dei confini fisici della camera il fruitore è libero di muoversi anche fisicamente. Un diverso approccio è stato adottato invece per la Web VR (fig. 9), sistema del quale lo user può beneficiare attraverso un laptop personale; si tratta di un metodo più economico tra quelli sperimentati e di più rapida accessibilità: infatti, mediante una connessione internet ed un link si accede ad un file html che contiene i modelli digitali, navigabili tramite mouse e comandi a tastiera. In tutti i casi il visitatore può navigare virtualmente sia nella piazza antistante la Scuola, piazza Petrarca, che passeggiare nel chiostro e entrare nella sala del Consiglio attraverso l'andito e la sagrestia. In questi termini, è possibile pensare ai luoghi della Scuola, ma anche di altri casi simili diffusi in tutta la città, come un museo virtuale che non impone la presenza fisica del visitatore sul posto. Alla realtà aumentata (fig. I0) sono invece

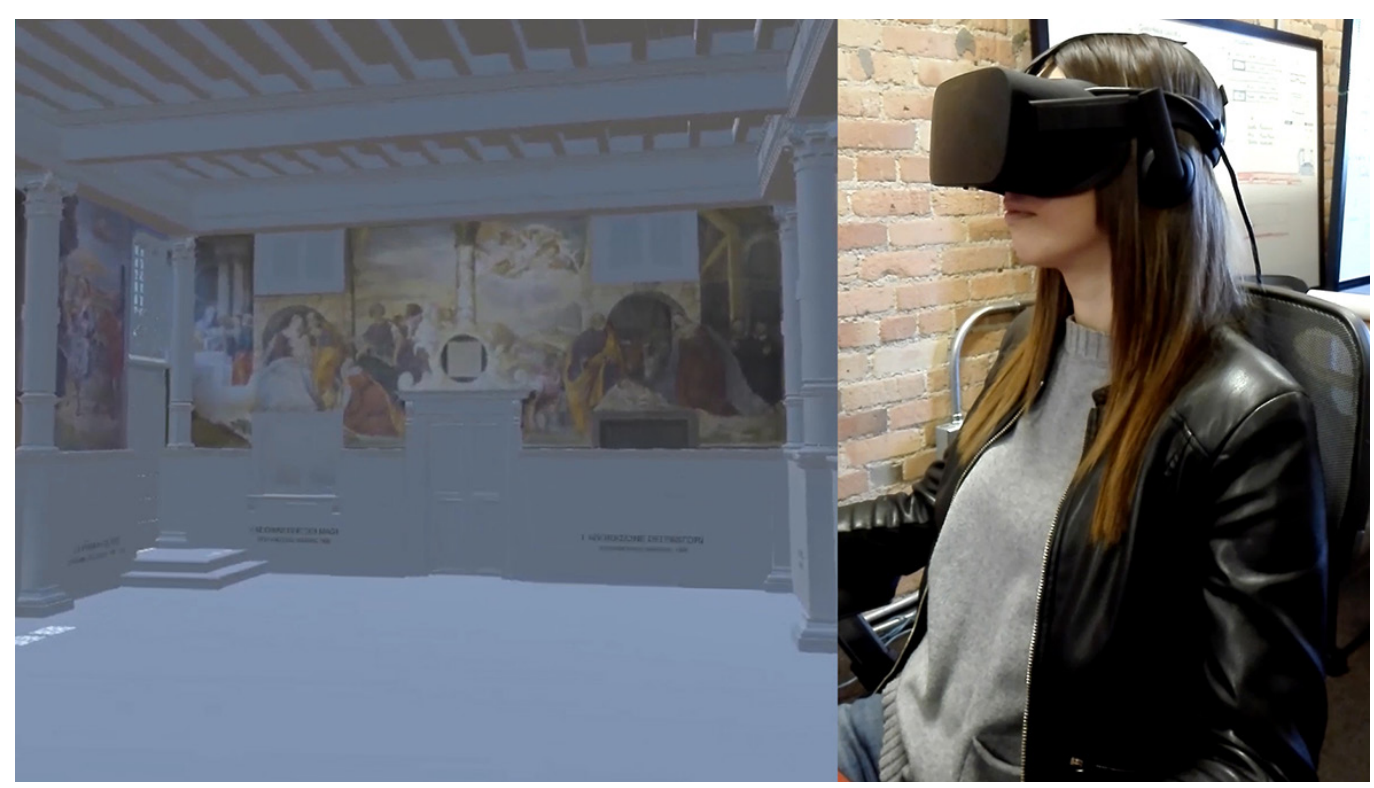


associate tutte le informazioni relative ai contenuti degli affreschi, sotto forma di immagini, grafici, testi e audio: informazioni, più in generale, di natura non associabile ai modelli digitali: per questo, l'utente con il proprio smartphone, mediante scansione dell'affresco o di un tag ad esso associato, ha la possibilità di indagare in situ le informazioni fornite e classificate per tematiche direttamente dal proprio schermo [9]. Dai risultati ottenuti si evince l'importanza del ruolo assunto al giorno d'oggi dalle tecnologie immersive ai fini della visualizzazione virtuale del patrimonio storico e artistico; l'uso di device immersivi induce un approccio di fruizione dinamico e coinvolgente da parte del visitatore. II controllo della visita diventa una scelta responsabile dell'utente invitato alla scoperta dell'edificio storico, sulla base dei propri interessi; l'adozione di queste tecnologie ha ormai da tempo avvicinato l'utente alla visualiz-

Fig. 7. Visualizzazione del modello BIM all'interno della camera immersiva Cave.
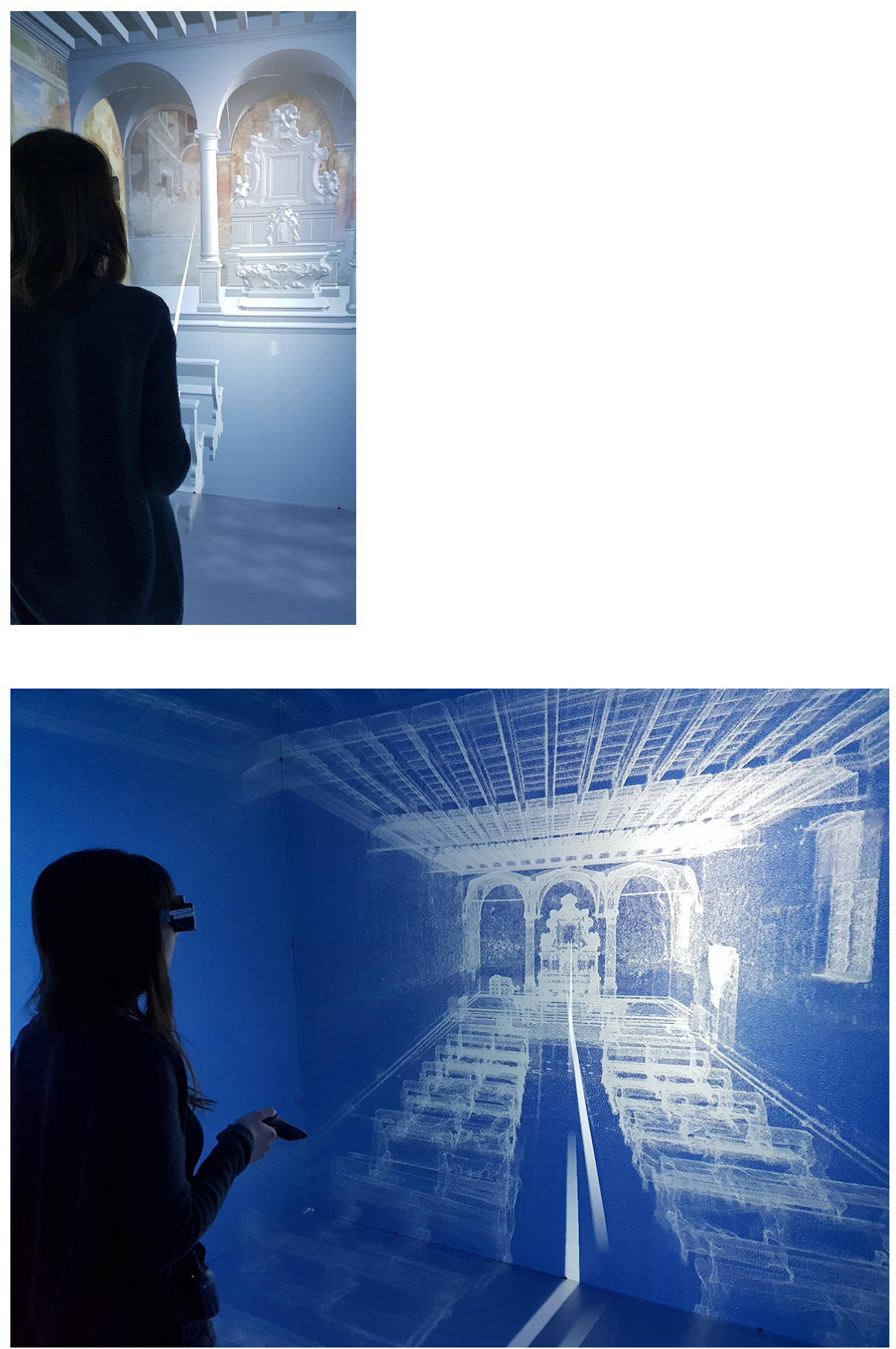
Fig. 10. Navigazione dei contenuti attraverso App per la realtà aumentata da dispositivo mobile.
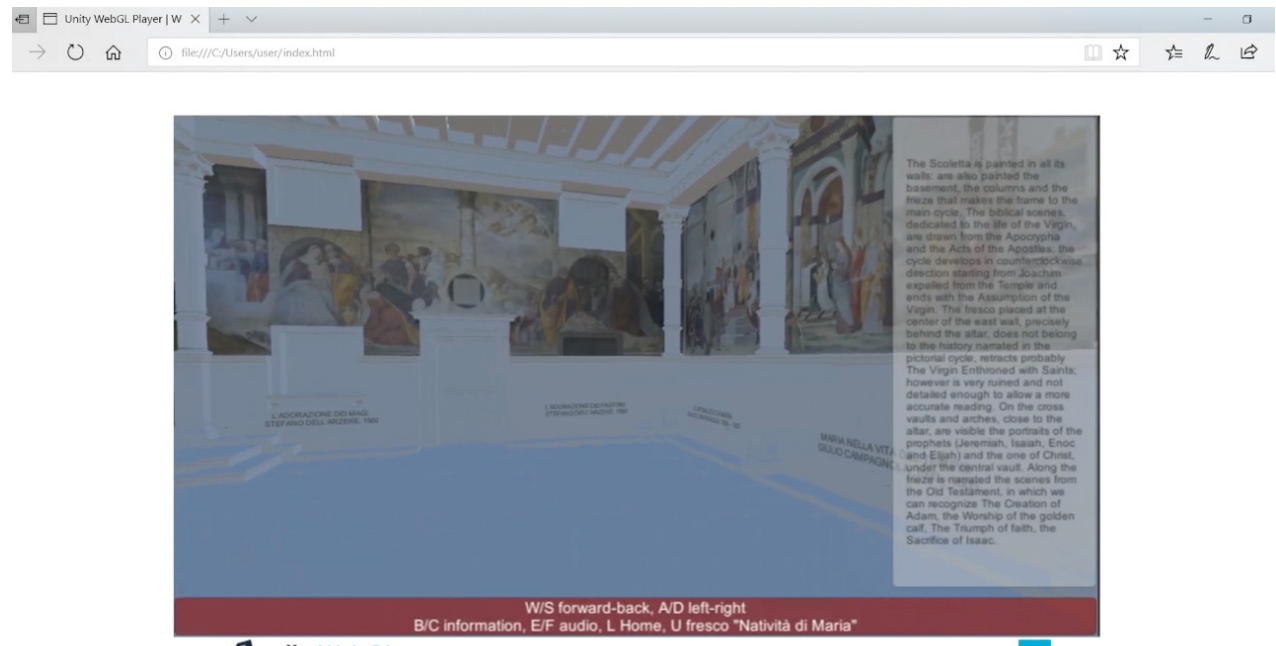

\&unity WebGL

WebVR $x^{\prime}$

zazione di tipo digitale e ha reso familiare l'approccio ai contenuti virtuali, sempre più simili alla realtà fenomenica. Tale principio semplifica quindi la lettura e l'interpretazione dei contenuti anche per gli utenti non esperti, configurandosi come visita intuitiva e personalizzabile. II museo virtuale, sempre più vicino alle capacità dell'utente, con tecnologie accessibili e di forte potere di attrazione, diventa un mezzo di diffusione rapida di contenuti e permette anche la promozione di quei siti culturali meno noti [I0].

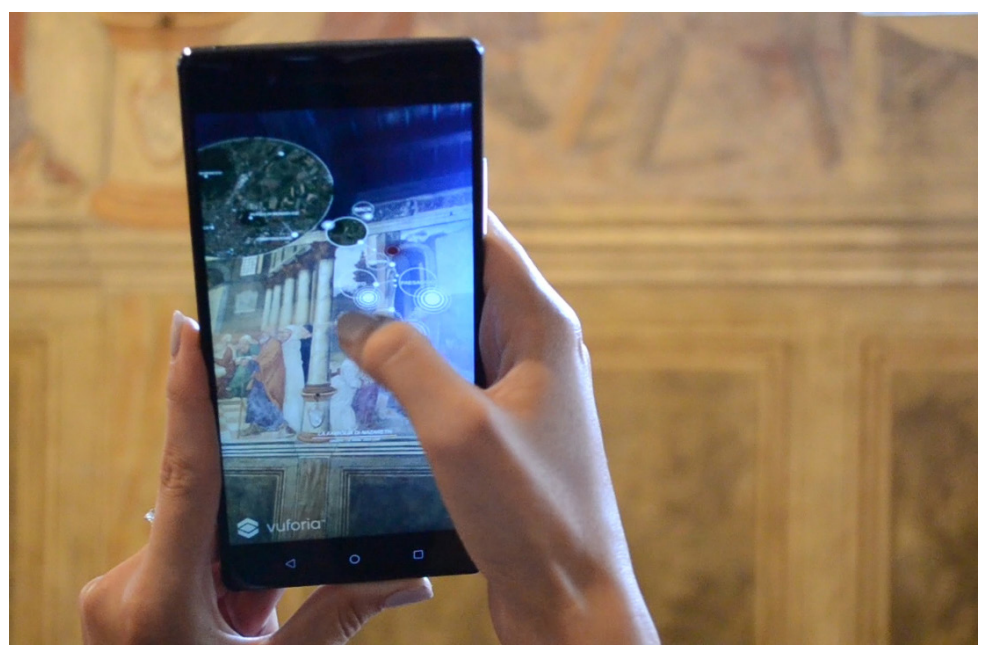

Note

[I] II progetto di ricerca inizia, nel marzo 20 I7, con un programma dal titolo Processi e metodi di Immersive Reality per il recupero la gestione e la fruizione turistica del patrimonio architettonico: La Scuola del Carmine a Padova, assegnista di ricerca dott.ssa Isabella Friso (Resp. Scientifico prof. C. Monteleone). Successivamente lo stesso caso studio viene analizzato nell'ambito de progetto di ricerca MONADIIIMetodologie per l'acquisizione, l'elaborazione e la comunicazione di dati relativi ai beni culturali e per il progetto architettonico e tecnologico di interventi atti alla loro conservazione e al miglioramento della fruizione turistico-culturale, cofinanziato dal Fondo Sociale Europeo (FSE), Resp. Scientifico prof. C. Monteleone, assegnisti di ricerca dott.sse Rachele Angela Bernardello, Mirka Dalla Longa, Emanuela Faresin e Giulia Piccinin.

[2] Ci si riferisce al contributo dal titolo Nuove forme di visualizzazione del bene culturale: la realtà immersiva e la Scuola del Carmine a Padova presentato al $39^{\circ}$ Convegno Internazionale dei Docenti delle Discipline della Rappresentazione UID, Napoli 14-16 Settembre 2017, e pubblicato nei relativi atti.

[3] La restituzione dell'orientazione interna viene poi applicata per eseguire il ribaltamento inverso per la ricostruzione metrico/geometrica degli enti rappresentati prospetticamente.

[4] II testo AA.W. ( 1988). Gli affreschi della Scoletta del Carmine. Padova: La Garangola, documenta l'intervento di restauro e i successivi studi sugli affreschi, a cui si fa riferimento in questo testo. 
[5] Le tecniche di trasferimento del disegno utilizzati sono: incisione diretta, incisione indiretta, spolvero.

[6] Si tratta de La Natività di Maria, L'Adorazione dei Magi, La Presentazione di Gesù al Tempio.

[7] II device utilizzato è l'Oculus Rift, un visore HDM - HeadMountedDisplay, che indossato dall'utente permette di visualizzare l'ambiente virtuale attraverso immagini stereoscopiche; viene utilizzato in abbinamento a opportuni sensori di posizione grazie ai quali l'immagine è sincronizzata ai movimenti della testa dello user.

[8] La strumentazione utilizzata è il Cave del Duke Immersive Virtual Environment (DiVE), fornito, insieme ad un Oculus Rift, dalla Duke University del North Carolina (USA) dove è stata svolta parte del progetto di ricerca. Lo spazio virtuale in questo caso viene proiettato (dall'esterno) all'interno di una stanza costituita da 6 piani ortogonali di dimensioni $3 \times 3 \times 3$ metri all'interno del quale si trova l'utente.

[9] I contenuti riguardano la narrazione biblica, le biografie degli autori, le informazioni sui personaggi (principalmente i ritratti dei committenti o di personaggi di spicco della società dell'epoca ed estranei a contenuti biblici), le informazioni relative ai paesaggi dipinti, individuabili nel territorio limitrofo. Quest'ultimo tema è trattato in uno studio a sé stante, sempre all'interno del progetto di ricerca.

[I0] Isabella Friso ha scritto il paragrafo Dal rilievo al digitale: un percorso di ricostruzione di architetture dipinte; Rachele Angela Bernardello ha scritto il paragrafo Scoletta del Carmine tra architettura costruita e architettura dipinta; Giulia Piccinin ha scritto il paragrafo Gli ambienti della Scuola attraverso realtà aumentata e realtà virtuale.

\section{Riferimenti bibliografici}

AA.W (1988). Gli affreschi della Scoletta del Carmine. Padova: La Garangola.

Albisinni Piero, Ippoliti Elena (2016). Musei Virtuali. Comunicare e/è rappresentare. In DisegnareCon, vol. 9 n. I7, Dicembre 2016.

Borchia Rosetta, Nesci Olivia (2008). II paesaggio invisibile. Ancona: II Lavoro Editoriale.

Bortot Alessio (2016). Rappresentare i confini. Percorsi di ricerca tra scienza e arte. Milano: Mimesis.

Ciammaichella Massimiliano, Bergamo Francesco (2016). Prospettive architettoniche dipinte nelle Ville Venete della Riviera del Brenta in provincia di Venezia. Roma: Aracne Editori.

Gasparotto Cesira (1955). Santa Maria del Carmine di Padova. Padova:Tipografia Antoniana.

Giordano Andrea et al. (20 I 8). The opportunities of the new digital tools. In Paesaggio Urbano (Urban Design), 4/20 I 8.

Giordano Andrea, Olson Mark (2018). Developing a methodology for historical visualization. In Huffman Kristin, Giordano Andrea, Bruzelius Caroline (eds.). Visualizing Venice. Mapping and modeling time and change in a city. London-New York: Routdlege.

Luigini Alessandro, Panciroli Chiara (a cura di). (20l8). Ambienti digitali per l'educazione all'arte e al patrimonio. Milano: Franco Angeli.

Manovich Lev (2009). Il linguaggio dei nuovi media. Milano: Edizioni Olivares.

Ratajczak Julia, Riedl Michael, Matt, DominikT. (20I9). BIM-based and AR application combined with location-based management system for the improvement of the construction performance. In Buildings 9/20 I 9.

Rodríguez-Moreno Concepcion et al. (2018). From Point Cloud to BIM: An Integrated Workflow for Documentation, Research and Modelling of Architectural Heritage. In Survey Review, 50 (360): pp. $212-231$.

Sgrosso Anna (1979). Note di fotogrammetria applicata all'architettura. Napoli: Lithorapid.

Sgrosso Anna (1996). La Rappresentazione Geometrica dell'Architettura.Torino: Utet.

Tang Pigbo et al. (20I0). Automatic reconstruction of as-built building information models from laser-scanned point clouds: A review of related techniques. In Automation in Construction, 19/7, pp. 829-843. Elsevier B.V.

Volk Rebekka, Stengel Julian, Schultmann Frank (20I4). Building Information Modeling (BIM) for existing buildings - Literature review and future needs. In Automation in Construction, 38, pp. 109-127.

\section{Autori}

Rachele Angela Bernardello, Università degli Studi di Padova, racheleangela.bernardello@unipd.it

Isabella Friso, Università luav di Venezia, ifriso@iuavit

Giulia Piccinin, Università luav di Venezia, gpiccinin@iuav.it

Per citare questo capitolo: Bernardello Rachele Angela, Friso Isabella, Piccinin Giulia (2020). Tecnologie immersive per la valorizzazione del patrimonio storico. I modelli digitali della scuola del Carmine/lmmersive technologies for the valorizzation of historical heritage. The scuola de Carmine's digital models. In Arena A., Arena M., Brandolino R.G., Colistra D., Ginex G., Mediati D., Nucifora S., Raffa P. (a cura di). Connettere. Un disegno per annodare e tessere. Atti del $42^{\circ}$ Convegno Internazionale dei Docenti delle Discipline della Rappresentazione/Connecting. Drawing for weaving relationships. Proceedings of the 42th International Conference of Representation Disciplines Teachers. Milano: FrancoAngeli, pp. 1720 - 1739. 


\title{
Immersive Technologies for the Valorizzation of Historical Heritage. The Scuola del Carmine's Digital Models
}

\author{
Rachele Angela Bernardello \\ Isabella Friso \\ Giulia Piccinin
}

Abstract

The research [I] proposes to analyse the 16th century pictorial cycle preserved on Scuola of Carmine, in Padua, one of the most ancient medieval fraglie of the city. Here we have the opportunity to show the outcomes of this research. The initial phases of the work were shown some years ago at the same conference [2].

The seventeen depicted frescos tell about some scenes of the Virgin's life from the Apocryphal Gospels. The project aims to realize a digital database for cultural and architectural heritage conservation and valorisation.

The research activities were organized in: a) acquisition of data (Laser Scanner 3D, Photo-Modelling, thermography and georadar) and all the historical documents; b) construction a interoperable database in order to collect documents, information about the case study; c) creation of a virtual interoperable model of the architecture, using Scan to BIM technologies; d) enforce the 3D virtual models with infographic information from database in order to obtain semantic models; e) test the semantic model with innovative tools.

Keywords

Cultural Heritage, cultural heritage, perspectical restitution, immersive tecnologies, BIM, virtual mesum.

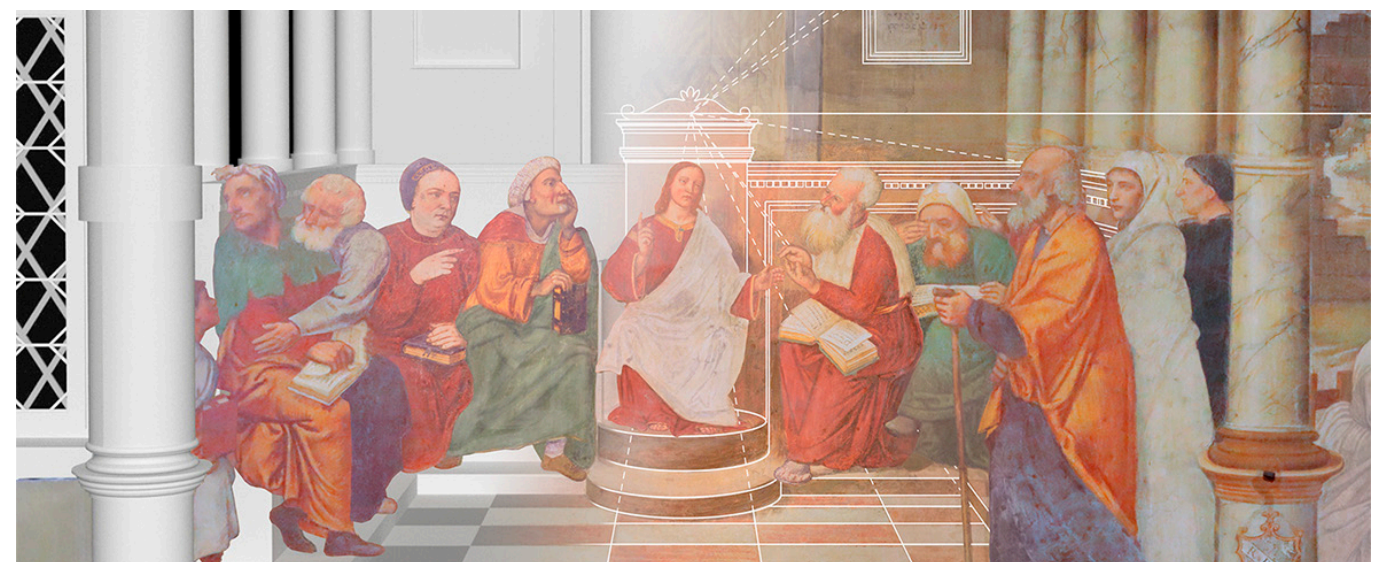




\section{From survey to digital model: a process for a digital reconstruction of depicted architecture}

The digital reconstruction of depicted architectures on pictorial cycle is a topic that allows to study the relationship between the different aspects linked to the Science of Representation: in fact starting from the recent technique of digital survey and producing images by computerized tools, it's not possible to neglect the descriptive geometry's theory, unknowing the projective laws of central projections and, in particularly, the perspective one. The 16th century pictorial cycle, the case study, is located on the walls of the medieval chapel of Carmini, in Padua (figs. I , 2). It was chosen because although it is inside of one of the most important monastic complex of Padua, first of all the citizens unknow it but also the city government has not given an appropriate valorisation to this cultural heritage, excluding it from touristic circuits.

Starting from an historical and archivist analyse the first step of this research go back to the phases of a developmental process, in a chronological way, underlining the main urban and architectural transformations of the religious complex of Carmini, including church, monastery and, of course, the little chapel.

The next step expects a digital survey campaign using laser scanner and photogrammetric technologies in order to document the current situation and create a semantic clone of architecture: the BIM model is based on all the historical documents and on the dense cloud obtained from digital survey. Moreover the textured model (obtained from the dense cloud) [Ciammaichella, Bergamo 2016] guarantees the four orthophoto of the walls, required to start the study and digital restitution of depicted architectures by Giulio and Domenico Campagnola, Girolamo dal Santo e Stefano dell'Arzere.

Finally, a georadar survey has taken over any construction anomalies and structural changes to the building.

The pictorial cycle was painted into a column system, on a high basement, that supports a trabeation. This is not a structural apparatus, but it is a perspective representation -in a vertical perspective- of a decoration system. It serves to divide the pictorial planes in different equal parts, where the episodes of Virgin's life are painted.

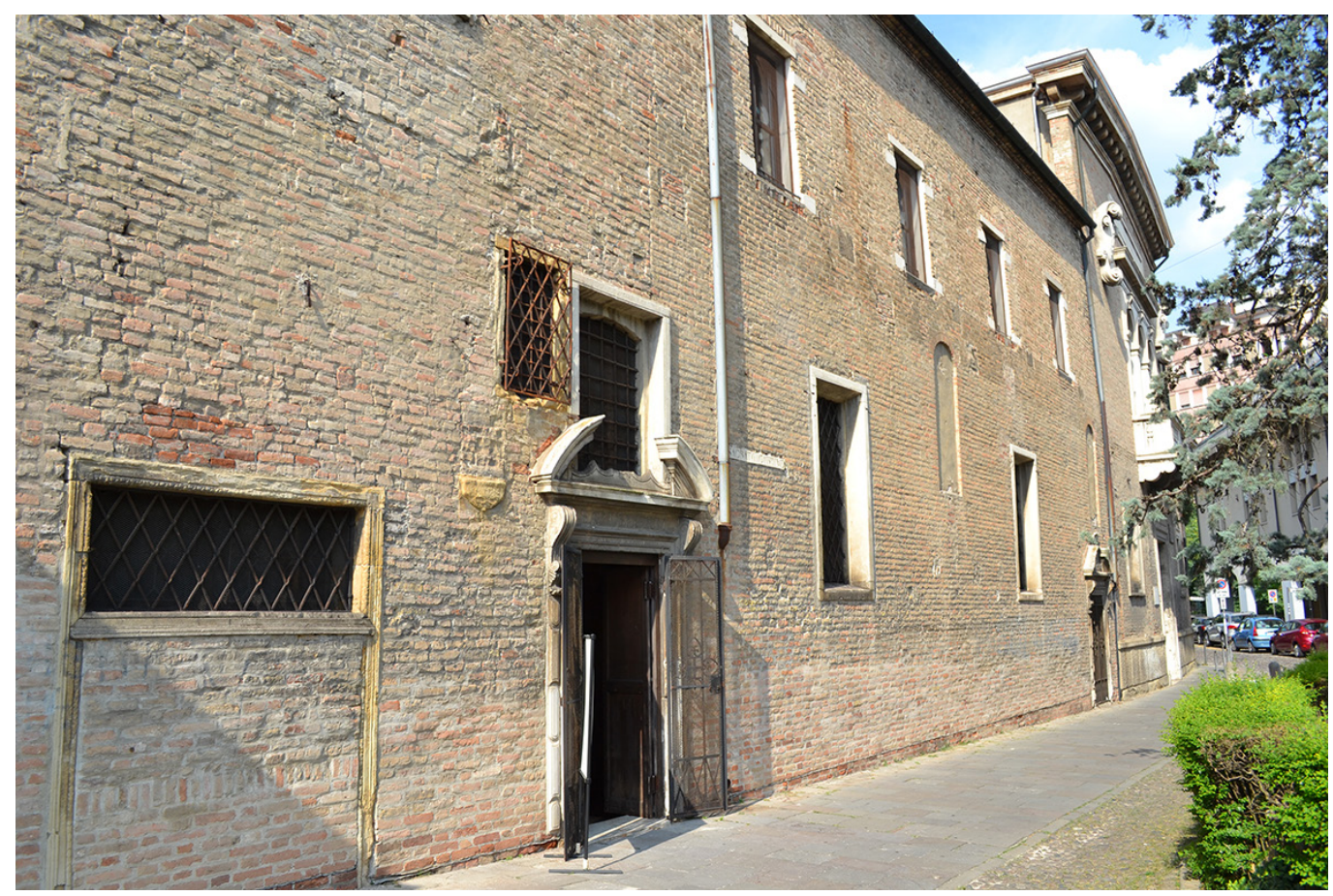


First of all, it was necessary to recognize the internal orientation [Sgrosso 1979] of every episode and, of course the exact position of the eye of the observer in the real space [3]. However it is necessary make some perspectival observations: first of all we have chosen the ground floor line coincident with the lower limit of frescos (at about $182 \mathrm{~cm}$ from the floor); for this reason the high of the observer is not always the same: in fact the ideal position of the observer doesn't take into account of the space of the constructing building, there isn't a strategic points inside the room; the observer can change his position and move inside the room. The reason depends on the presence of different painter in different years (fig. 3). So, the real position of the centre is a mandatory stopover of a fruitive path in which the observer change his position, although he is bound to the reading of the story.

All the painters used the vertical perspective to represent every episode. With this representation's method the shapes belonging to planes parallel to perspective one is projected in their real shape but not in their real dimensions. So, the buildings depicted on the walls keep their vertical walls as vertical lines on the drawing and some of their facades are drawn in their real shape.

The homologous correspondence between perspective projection and its first Monge's image (overturned under the ground floor line) was useful to establish the plans and facades of the buildings [Sgrosso 1979, pp. 8-19].

The two-dimensional drawings obtained applying the inverse perspective was elaborated in the virtual three-dimensional space in order to realize e digital model of the depicted scene (fig. 4).

All this material was useful for the next step of research that involve the Augmented and Immersive Reality experimentations. These new technologies open new frontiers in the Representation's field, overthrowing the boundaries imposed by paper support, changing the observer from a passive user to an interactive protagonist.

\section{Scoletta del Carmine between built architecture and painted architecture}

The concept of space within the scoletta del Carmine is formulated in a joint relationship between the built physical space and the painted space [4], only observable without entering it. Both of them exist with their own rules and their own codification, but necessarily

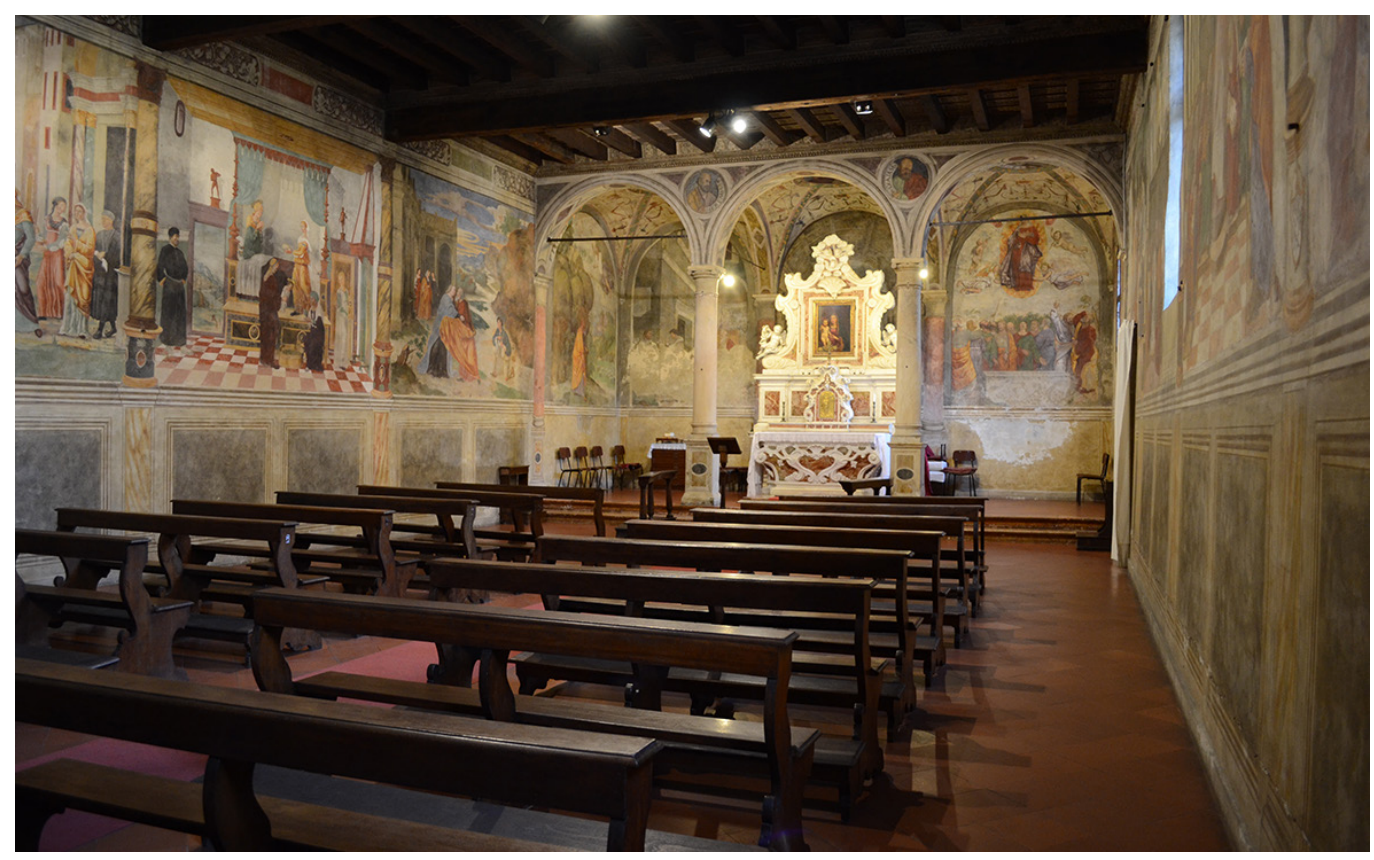


Fig. 3. Orthogonal projections of the buildin and positions of the observer of the perspective for each scene (graphoc elaboration by l. Friso e $\mathrm{G}$. Piccinin). undergo and exert an influence on the other, changing the perception of the user on the volume in which he/her is immersed and observes.

The Scan-to-BIM reconstruction process of the ancient fraglia has allowed, through the point cloud with RGB values, to manage, discretize and represent both architectural and graphic information in a virtual environment. Therefore, starting from the survey parallel

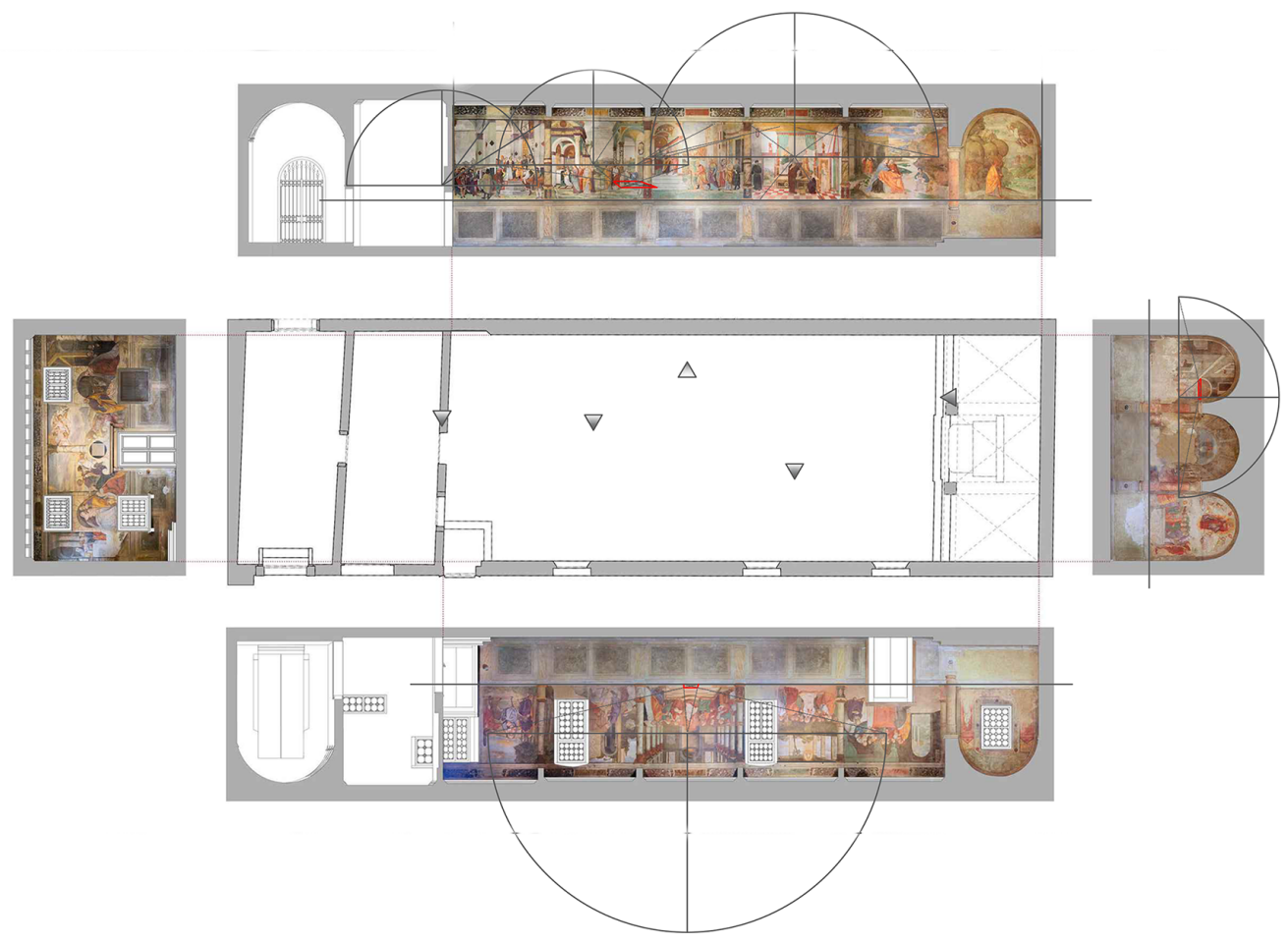

pathways have followed in order to return the two dimensions and to be able to use at least in virtual space their spatial interaction, created in the real contest by the observer visual process.

Through a visual reconstruction of the built space transformations occurred in time, the architectural changes of demolition and reconstruction have been highlighted and explored through virtual applications [Giordano et al 2018, p. 52].

The connection and interdependence between geometry, parameters and relations themselves, typical of object modelling, used for the reconstruction of architectural systems, allowed to query and explain in the digital clone the as built structure, but also the different events that modified the ancient Refectory, through the mapping and organization of archive documents and historical sources.

Based on this logic, the painted architecture has been treated within the BIM model as a built system. Each fresco was in fact considered as an effective and unique component within the model, describing not only the dimensional parameters, but also populating it with related information including author, bibliographical references and drawing transfer method [5].The filter architectural element, columns and entablature, which surrounds the frescoes and makes the external-internal effect credible, has been identified as an exclusive element integrated with its identity and function both in the model database and consequently in the elaborations in the visualization tools.

The temporal dimension is thus inserted into the BIM model through the organization of different types of parameters and the value compilation for each object. Moving then from 
the dating of individual elements towards the creation of macro-phases, allows you to filter and group the information according to criteria defined by the model use, in particular for the scoletta the architectural changes that have had an effect in the frescoes:

- 1313- 1492: period of construction of the convent of Santa Maria del Carmelo. The room of the present scoletta is used as a refectory for the friars;

- 1492- 1505: after the collapse of the east wall of the church, the fraglia was moved to the ground floor, thus the pictorial decoration of the scoletta began;

- 1505-1600: end of the present pictorial cycle, with the construction of a wall, the current west wall - that divides the scoletta from the sacristy;

- 1600-20 I 8: suppression of the fraglia and in particular the two current access doors from the churchyard are inserted and a window in the door is modified. Moving the altar far from the east wall.

In this way it is possible to move along the timeline, by exploring and querying the model, and to understand not only the architectural changes, but also to visualize the pictorial cycle in different historical moments. For example, visiting the scoletta without the presence of the
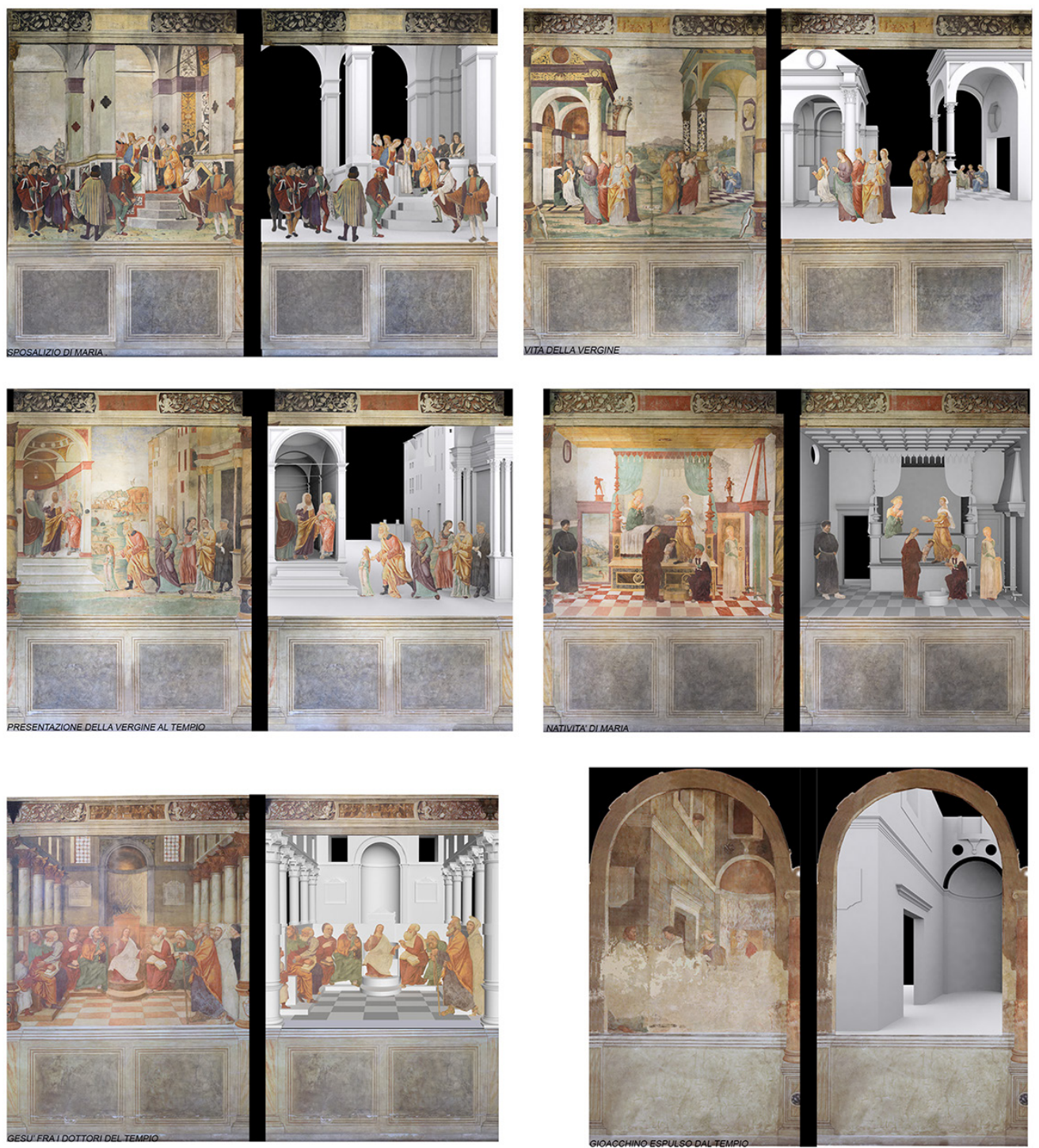
west wall erected by the confraternity, without the scenes on it [6], thus entirety capturing the first configuration with the atrium frescoes, now only partially visible. In addition, the possibility of integrating into the digital information model the three-dimensional reconstruction of the painted environments, obtained from the perspective restitution, provides for each phase a further level of involvement, being able to enter a generally immobile scenario background to the movement of the bodies.

It should also be noted that the state of conservation of the frescoes is strictly connected to the use of the built space and its structural nature. Over time, function changes have caused losses and deterioration of the frescoed surface, for example the movement of the altar. The BIM model is therefore the basis for analyses and simulations, to support the activities of knowledge and conservation of the I6th century frescoes [Volk 20 I4, p. I I0] An overlapping of the point cloud with the BIM model made it possible to highlight structural and out of plumb differences, in particular for the perspective reconstruction of the fresco environments it was possible to determine the inclination of the painting plane.
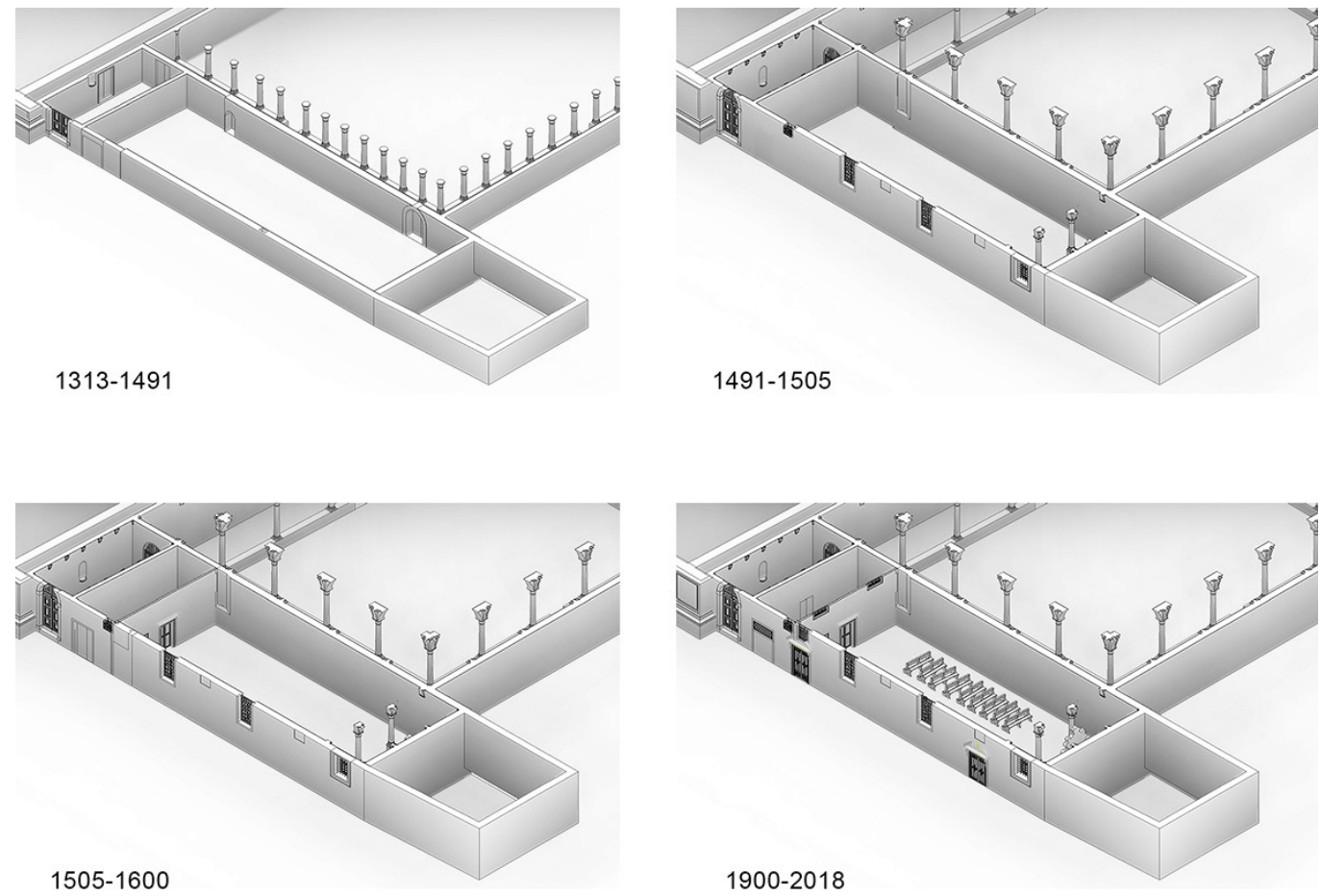

\section{The spaces of the scoletta through augmented reality and virtual reality}

The 3D modelling process, which is an essential tool for integrating environments that are different in matter, allows to unify them, matching complementary information coming from each one, and turning them into a single environment, the immaterial virtual one. The rigorous application of the analysis and modelling procedures has allowed the production of a group of information because of the various research field involved. The immersive technologies tested, during this research, provide the opportunity to organize all types of 
information and make it usable for a dual purpose: for maintenance and management, but above all for visiting use, in terms of virtual museum. Therefore, the devices selected for the experimentation of digital models, which are chosen from those available commercially, have shown, by comparing their results, different performance, costs, and methods of use. Keeping into consideration the aim to involve a large audience, the choice of instruments also considered the characteristics of the hypothetical final user: age, level of school education, cultural background, and interests. For this reason, the devices adopted change substantially due to the possibility left to the user to control and customize his visit.

A Head Mounted Display [7] (fig. 6) mainly granted the possibility to load a predefined tour, supporting the different types of input data: the digital models but also the point cloud provided by the digital survey, images and audio files. In this first hypothesis, the instrument isolates the ideal visitor from the real world, which he is used to know: his physical movements, in fact, are not involved in the virtual visit. Although, more freedom is granted to the hypothetical visitor in case of using the models inside an immersive room [8]; in this case the user, who is inside it and is equipped with a controller and special LCD glasses, can navigate the environment (fig. 7) and obtain textual information, point cloud (fig. 8), images, audio, directly activating commands in the model. Once the historical phase of interest has been selected, it is possible, for example, to view the entire original cycle of frescoes, in his original configuration with the scenes left today in the sacristy, or ask information to specific tags that trace the events related to the story of the Carmelite order in Padua, or even read historical sources such as ancient documents or view historical maps. Within the physical boundaries of the immersive room, he is also free to move physically inside it. Although, a different approach has been adopted for Web VR (fig. 9), a system in which the user can enjoy the visit through a personal laptop; it is the cheapest method among those tested and the quickest to access: using a link and a web connection it is possible to enter an html file that contains the digital models, navigable using keyboard commands. In all cases, the visitor can virtually navigate both in the square in front of the school, named piazza Petrarca, walk in the cloister and enter the Sala del Consiglio, the main room, through the entrance and the sacristy. In these terms, it is possible to consider the spaces of the scoletta, as well as other similar cases spread throughout the city, like a virtual museum with no need to be properly inside the building itself. Moreover, augmented reality (fig. I0) is possible to obtain all the information related to the contents of the frescoes, in the form of images, graphics, texts and audio: we may say, more in general, all typologies of information that cannot be linked to the 3D models. The user with his personal smartphone, by scanning the fresco or a tag associated with it, has the possibility to investigate the information provided and classified in different topics directly from his mobile [9].

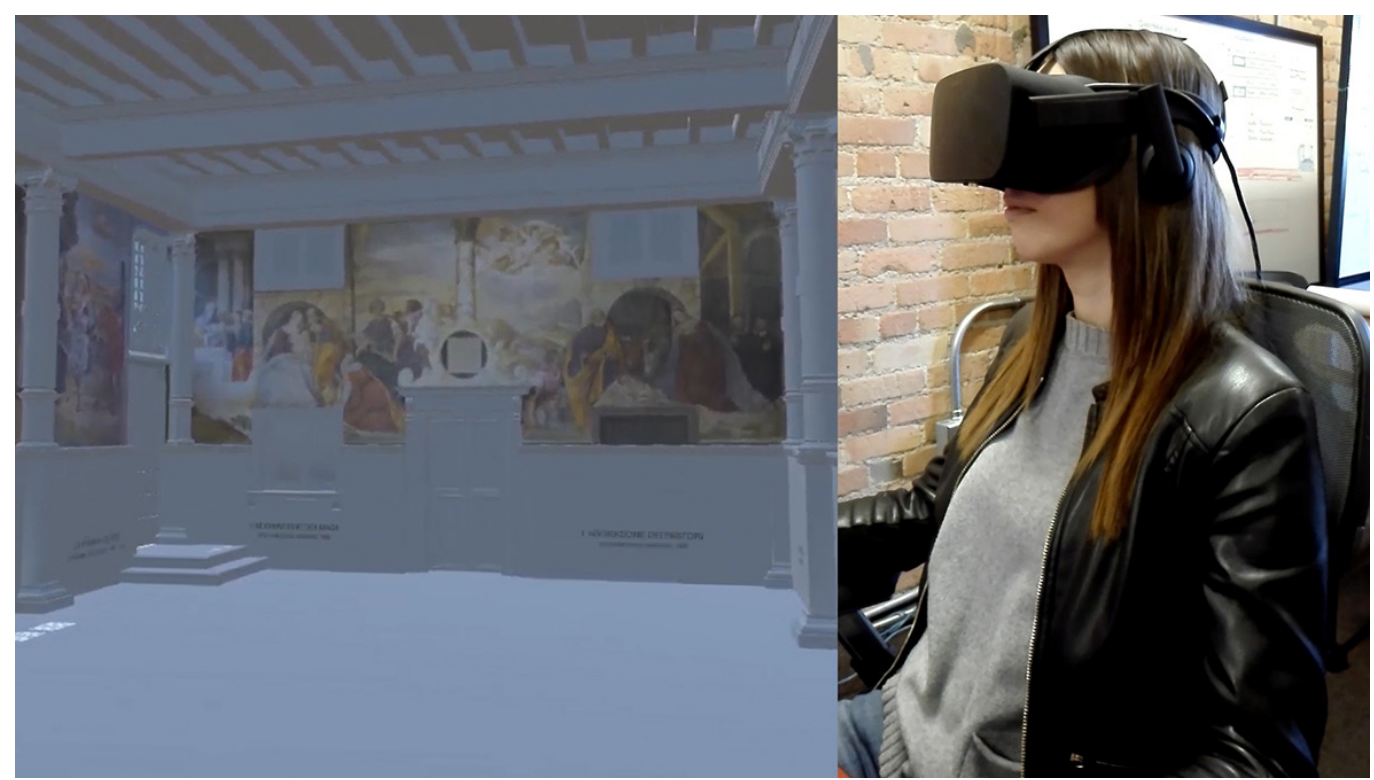


The results obtained show the importance of the role that immersive technologies have nowadays for the purpose of three-dimensional visualization of the historical and artistic heritage; the use of immersive devices induces a dynamic and addictive fruition approach by the visitor. The visit control becomes a choice of the users, who are invited to discover the historical building according to their own interests; the use of these technologies has brought the user close to digital visualization and has made the approach to virtual contents more familiar, always more similar to the material reality. Therefore, this idea simplifies the
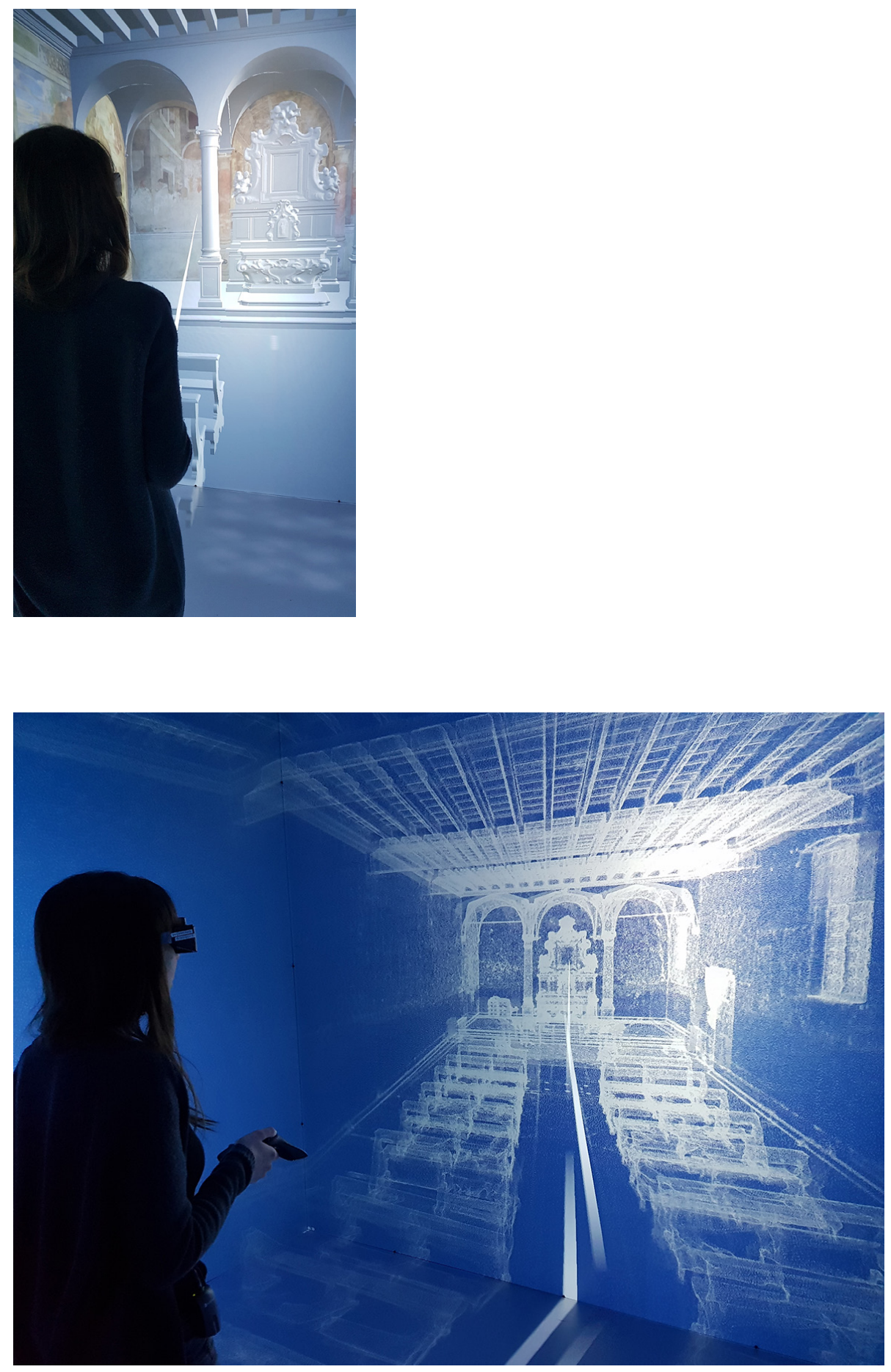
Fig. 9. Visualization of the digital models in the WebVR system.
Fig. 10. Browse of the contents of the frescoes by augmented reality App using a mobile device.
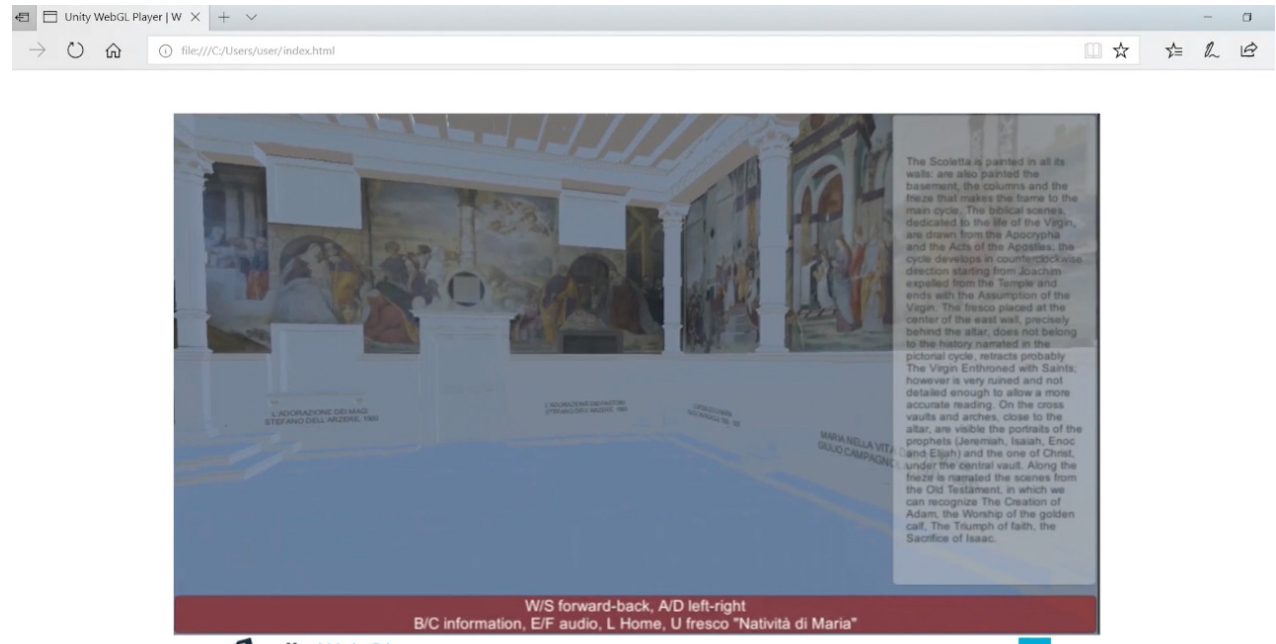

\&unity WebGL

WebVR $x^{x}$

reading and interpretation of content even for non-expert users: the visit is more intuitive and customizable. The virtual museum, closer to the user's skills, because of the application of easy understandable technologies and its strong attraction power, becomes an easy way to share contents and also allows the promotion of those lesser-known cultural sites [10].

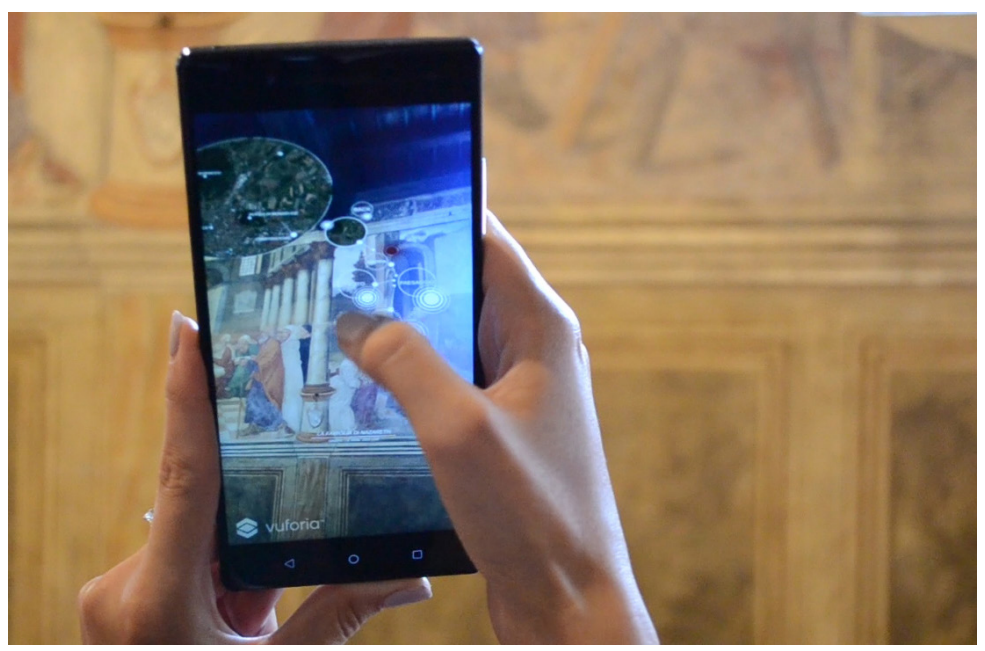

Notes

[I] This project started on March 2017. The title of the program is Processi e metodi di Immersive Reality per il recupero, la gestione e la fruizione turistica del patrimonio architettonico: La Scuola del Carmine a Padova, Scientific Coordinator prof. Cosimo Monteleone, research fellow. Then the same case study was analyzed in the other project MONADII/Metodologie per l'acquisizione, l'elaborazione e la comunicazione di dati relativi ai beni culturali e per il progetto architettonico e tecnologico di interventi atti alla loro conservazione e al miglioramento della fruizione turistico-culturale, cofounded by Fondo Sociale Europeo (FSE) Scientific Coordinator prof. Cosimo Monteleone. This last research involved some researcher fellow Rachele Angela Bernardello, Mirka Dalla Longa, Emanuela Faresin and Giulia Piccinin.

[2] We are talking about the paper titled Nuove forme di visualizzazione del bene culturale: la realtà immersiva e la Scuola del Carmine a Padova sowed at $39^{\circ}$ Convegno Internazionale dei Docenti delle Discipline della Rappresentazione UID, Napoli September 14-16,2017, and published on the relative book.

[3] It is possible to recognize the internal orientation applying the inverse overturning method of perspective.

[4]The text AA.W. (1988). The frescoes of the Scoletta del Carmine. Padua: La Garangola, documents the restoration work and subsequent studies on the frescoes, to which reference is made in this text. 
[5] The drawing transfer techniques used are direct engraving, indirect engraving and dusting.

[6] These frescoes are: The Nativity, The Adoration of the Magi, The Presentation of Jesus in the Temple.

[7] The device which has been used is Oculus Rift, a Head Mounted Display; when it is worn by the user it allows to view the virtual environment through stereoscopic images; it is used together with appropriate position sensors, thanks to which the image is synchronized with the user's head movements.

[8] The instruments used is the Cave by Duke Immersive Virtual Environment (DiVE), provided by the Duke University North Carolina (USA), together with the Oculus Rift; at the Duke University was carried out a part of the research project. In the Cave, the virtual space is projected (from the outside) into a room consisting of 6 orthogonal floors of dimensions $3 \times 3 \times 3$ meters inside which the user is located.

[9]The contents concern the biblical story, the biographies of the painters, information on the characters (mainly the explanation of the portraits of the clients or important personalities of the society and unrelated to biblical content), information related to the painted landscapes, identifiable in the surroundings of Padua. The latter topic is dealt with in a separate study always within the research project.

[I 0] Isabella Friso wrote the paragraph From survey to digital model: a process for a digital reconstruction of depicted architecture: Rachele Angela Bernardello wrote the paragraph Scoletta del Carmine between built architecture and painted architecture; Giulia Piccinin wrote the paragraph The spaces of the Scoletta through augmented reality and virtual reality.

\section{References}

AA.W (1988). Gli affreschi della Scoletta del Carmine. Padova: La Garangola.

Albisinni Piero, Ippoliti Elena (2016). Musei Virtuali. Comunicare e/è rappresentare. In DisegnareCon, vol. 9 n. I7, Dicembre 2016.

Borchia Rosetta, Nesci Olivia (2008). Il paesaggio invisibile. Ancona: Il Lavoro Editoriale.

Bortot Alessio (20 16). Rappresentare i confini. Percorsi di ricerca tra scienza e arte. Milano: Mimesis.

Ciammaichella Massimiliano, Bergamo Francesco (2016). Prospettive architettoniche dipinte nelle Ville Venete della Riviera del Brenta in provincia di Venezia. Roma: Aracne Editori.

Gasparotto Cesira (1955). Santa Maria del Carmine di Padova. Padova:Tipografia Antoniana.

Giordano Andrea et al. (20।8). The opportunities of the new digital tools. In Paesaggio Urbano (Urban Design), 4/20 I 8.

Giordano Andrea, Olson Mark (2018). Developing a methodology for historical visualization. In Huffman Kristin, Giordano Andrea, Bruzelius Caroline (eds.). Visualizing Venice. Mapping and modeling time and change in a city. London-New York: Routdlege.

Luigini Alessandro, Panciroli Chiara (a cura di). (20l8). Ambienti digitali per l'educazione all'arte e al patrimonio. Milano: Franco Angeli.

Manovich Lev (2009). II linguaggio dei nuovi media. Milano: Edizioni Olivares.

Ratajczak Julia, Riedl Michael, Matt, DominikT. (2019). BIM-based and AR application combined with location-based management system for the improvement of the construction performance. In Buildings 9/2019.

Rodríguez-Moreno Concepcion et al. (20 I 8). From Point Cloud to BIM: An Integrated Workflow for Documentation, Research and Modelling of Architectural Heritage. In Survey Review, 50 (360): pp. 21 2-231.

Sgrosso Anna (1979). Note di fotogrammetria applicata all'architettura. Napoli: Lithorapid.

Sgrosso Anna (1996). La Rappresentazione Geometrica dell'Architettura. Torino: Utet.

Tang Pigbo et al. (20 I0). Automatic reconstruction of as-built building information models from laser-scanned point clouds: A review of related techniques. In Automation in Construction, 19/7, pp. 829-843. Elsevier B.V.

Volk Rebekka, Stengel Julian, Schultmann Frank (20I4). Building Information Modeling (BIM) for existing buildings - Literature review and future needs. In Automation in Construction, 38, pp. 109- 127.

\section{Authors}

Rachele Angela Bernardello, Università degli Studi di Padova, racheleangela.bernardello@unipd.it

Isabella Friso, Università luav di Venezia, ifriso@iuav.it

Giulia Piccinin, Università luav di Venezia, gpiccinin@iuav.it

To cite thos chapter. Bernardello Rachele Angela, Friso Isabella, Piccinin Giulia (2020). Tecnologie immersive per la valorizzazione del patrimonio storico. I modelli digitali della scuola del Carmine/lmmersive technologies for the valorizzation of historical heritage. The Scuola del Carmine's digital models. In Arena A., Arena M., Brandolino R.G., Colistra D., Ginex G., Mediati D., Nucifora S., Raffa P. (a cura di). Connettere. Un disegno per annodare e tessere. Atti del $42^{\circ}$ Convegno Internazionale dei Docenti delle Discipline della Rappresentazione/Connecting. Drawing for weaving relationships. Proceedings of the 42th International Conference of Representation Disciplines Teachers. Milano: FrancoAngeli, pp. $1720-1739$. 